Historic, Archive Document

Do not assume content reflects current scientific knowledge, policies, or practices. 


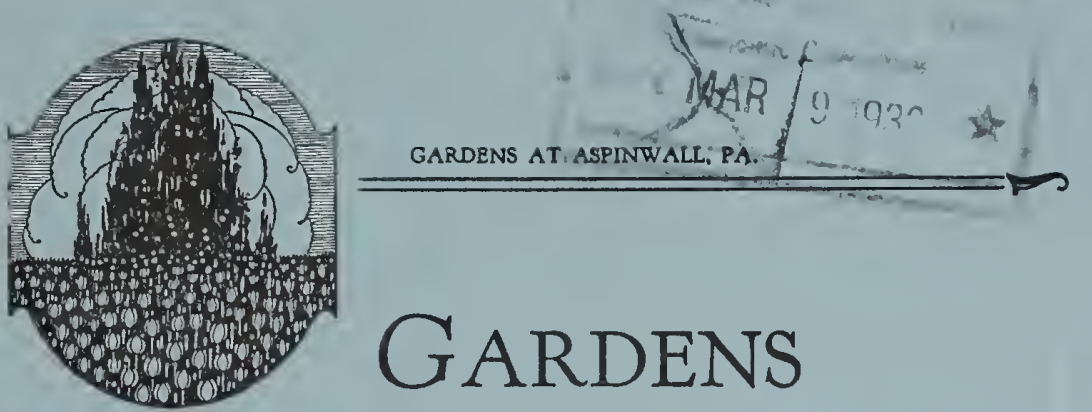

Specialists in Flowering Bulbs and Genuine English Flower Seeds CHESWICK, PENNSYLVANIA.

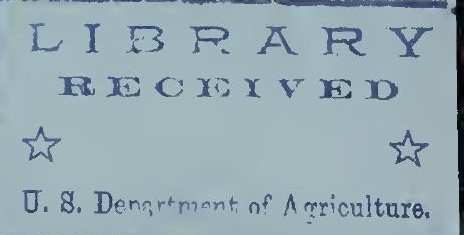

\section{Genuine English Flower Seeds}

A garden is limited for space and cannot afford to harbor anything which does not yield richly in beauty and satisfaction. The possibilities of beauty and satisfaction, even from a little space, are so great that they ought not to be slighted for the sake of a few cents, or a few dollars. And the cost of seeds for planting--even rare and excellent seeds--is so trifling that there seems to be no justification for using any but the best.

Believing that the patrons of SCHENLEY GARDENS will take this view, we offer only the finest flower seeds that we can get--English flower seeds. Not good because they are English but English because the best flower seeds are grown in England. We go there for the best, just as we go to Holland for the most superior tulips, or to Japan for the most exquisite lilies.

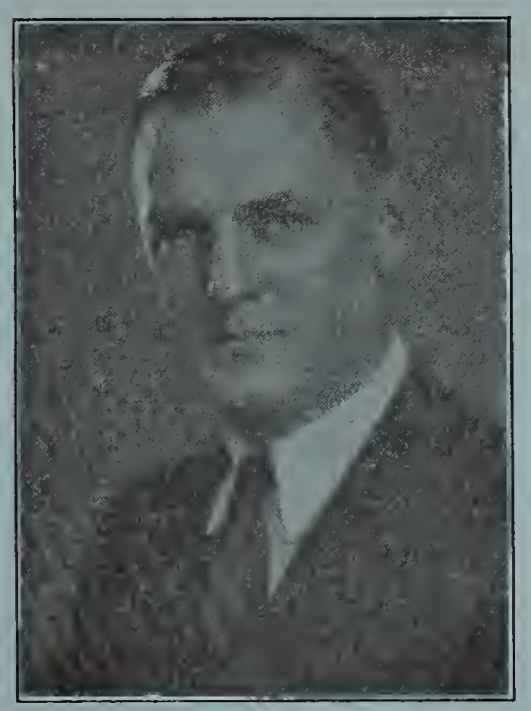

The most lovely and desirable varieties, true to type, true to name, trus to color, selected for sure germination and vigorous growth-- the seeds here offered will produce all that you hope for in the planting of your garden.

SCHENLEY GARDENS, INC.

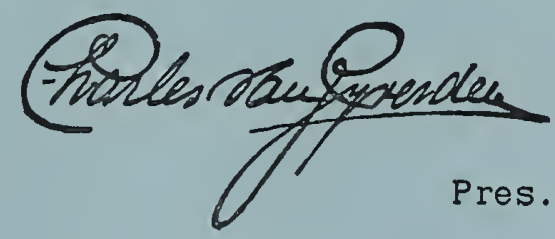




\section{ACONITUM}

203 FISCHERI WILSONI. Handsome light blue flowers in September. hP. 5 to $6 \mathrm{ft}$. Pkt. 35 cts.

\section{AGERATUM}

111 BLUE PERFECTION. Compact edging plants with large heads of mauve-blue flowers. Pkt. $10 \mathrm{cts}$.

\section{ALYSSUM}

121 PROCUMBENS. Sweet Alyssum; Carpet of Snow. The finest of all edging plants, making a perfect ribbon of white. Pkt. 10 cts.

122 SAXATILE COMPACTUM. Golden Alyssum. A low edging perennial producing masses of bright yellow blooms which contrast pleasingly with white and blue flowers 6 inches high. Pkt. 25 cts.

\section{ANCHUSA}

2 ITALICA, LISSADELL. Handsome border plant producing flowers of intense gentian-blue, larger than those of the Dropmore variety. hP. $41 / 2 \mathrm{ft}$. Pkt. 25 cts.

\section{ANTIRRHINUM - SNAPDRAGON}

With massive spikes of curious flowers rich as crimson velvet, or with graceful sprays dainty as apple-blossoms, Snapdragons have a kaleidoscopic beauty for either bedding or cutting. We list here our splendid blends of famous varieties. These will produce a glorious display of myriad colors.

These perennials are best treated as annuals. Massed in beds or in front of shrubbery borders, they bloom steadily throughout the whole summer and autumn, providing a superb display of graceful, many-colored flowers especially good for cutting.

\section{TALL LARGE-FLOWERING ANTIRRHINUMS}

These handsome plants grow 3 to 4 feet high, producing fine $11 / 2$-foot spikes. They look best in solid masses, bordered by a suitable low edging. Violas and forget-me-nots are good in front of the pure white, pale yellow, and appleblossoms sorts. Alyssum looks better before the crimson, brown, and copper shades.

175 SCHENLEY GARDENS SPECIAL SHOW MIX-

TURE OF TALL PRIZE SNAPDRAGONS, contains

18 beautiful colors. Extra-large pkt. 25 cts.

176 SCHENLEY GARDENS SPECIAL SHOW MIX.

TURE SEMI-DWARF PRIZE SNAPDRAGONS, contains 18 beautiful colors. Extra-large pkt. 25 cts.

\section{NEW GIANT SNAPDRAGON}

Grand border plants, producing very long spikes of im. mense flowers on vigorous plants 3 to $31 / 2$ feet high. Many beautiful shades mixed, per pkt. $25 \mathrm{cts}$.

\section{AQUILEGIA}

COLUMBINES are so vividly alive with an eager, elfin grace, a fluttering rapture like the wings of birds and butterflies! They dance across your garden year by year, for once they like you they never go away.

191 SCHENLEY GARDENS EXTRA-SELECTED HY. BRIDS. Broad-petaled long spurred flowers, pure white,

blush, pink and rosy scarlet, dark blue and pale blue, primrose and rich yellow. Pkt. 25 cts.

22 SCHENLEY'S GLORY STRAIN. A very beautiful selected strain raised at the famous Taplow Nurseries, England. They bear large, elegant, long-spurred flowers in the greatest variety of color-delicate blues and laven. ders, roses, pinks, red and gold, and yellow and prim. rose, etc. hP. $2 \frac{1}{2} \mathrm{ft}$. Pkt. $50 \mathrm{cts}$.

\section{ASTERS}

AMERICAN BEAUTY ASTERS. This type bears large : flowers with incurved petals, like a chrysanthemum, on stems $1 \frac{1}{2}$ to 2 feet long. They commence blooming in August and provide the finest sort of cut-llowers.

236 SCHENLEY MIXTURE OF BEAUTIFUL COLORS. Pkt. $25 \mathrm{cts}$.

CALIFORNIA GIANT DOUBLE is the last word in genuine quality. Long stems superbly crowned with enormous, plumy flowers of favorite colors.

217 MIXED COLORS. Pkt. $25 \mathrm{cts}$.

EARLY WONDER ASTERS. These are the earliest blooming Asters. March-sown seedlings, set out in May, commence blooming in June.

247 ALL COLORS MIXED. Pkt. 15 cts.

IMPROVED SUNSHINE ASTERS. The prettiest and most graceful of all Aster types for cutting. The plants grow about 18 inches high and have good, stout stems.

181 CARMINE.

182 LAVENDER.

Each, pkt. 25 cts. 185 All Colors mixed, per pkt. 25 cts.

HARDY PERENNIAL ASTERS. For large masses of soft, elegant color in late summer, Michaelmas Daisies are supreme. The lowers range through many shades of bluish lavender, pink, and purple, coming in great clusters. They are good in large borders or at the edge of shrub. bery. 291 Pkt. 25 cts.

\section{CALENDULA}

OFFICINALIS. Pot Marigold. These are the "Marygolds" of Shakespeare's time, and have lately become one of the most popular annual lowers for bedding and cutting, because of their rapid growth and general usefulness.

342 ORANGE KING. Large, double flowers of intense, glowing orange. Pkt. $10 \mathrm{cts}$.

345 MIXED VARIETIES. A splendid assortment of colors and forms. Extra-large pkt. 25 cts.

\section{SCOTCH MARIGOLDS}

CALENDULAS are homey, and wholesome, and every. body likes them.

341 THE BALL is the new, perfectly double, orange-yellow sort the florists raise. Pkt. 25 cts.

\section{CAMPANULA CANTERBURY BELLS}

MEDIUM. These are the true Canterbury Bells, with single, bell-like flowers most gracefully arranged on long, upright stems. Splendid massed, or grouped in the border.

380 SPLENDID MIXTURE: Blue, Rose, Mauve, and White. Pkt. 10 cts. 


\section{CALYCANTHEMA}

The Cup-and-Saucer type. Blooms the second year from seedlings started in April and set out in their permanent places by the middle of July. Cultivate well and water them when dry. Protect very lightly from damp and wet during the winter. $21 / 2$ feet high.

387 CHOICE MIXED. Pkt. 15 cts.

CAMPANULA calycanthema,

381 DOUBLE. A handsome new strain of the Cupand. Saucer Canterbury Bells, producing over 50 per cent flowers with the cup duplicated and ruffled in Purple, Blue, Pink, Lilac, White, and Striped. Mixed colors. pkt. 50 cts.

\section{CANARY-BIRD VINE}

(Tropoeolum canariense). A very pretty annual climber with bright yellow blossoms of bird-like form. It comes originally from the tropical regions of South America and should not be planted until the ground is warm. The curiously cut foliage is just as interesting as the flowers. It grows quickly to considerable height.

421 SELECT SEED. Pkt. 10 cts.

\section{CANDYTUFT}

(Iberis). One of the most important annuals for garden, edging, and mass bedding, bearing large heads of attractive white and variously colored flowers.

431 GIANT HYACINTH-FLOWERED WHITE. Specially selected seed, producing immense pure white flowers. Pkt. 10 cts.

\section{CARNATIONS DIANTHUS}

Most desirable flowers for fragrance in the garden.

CHOICE HARDY BORDER. Perpetual bloomers. A new type producing a great variety of fancy flowers.

441 SPECIAL MIXTURE. Various colors. Pkt. 25 cts.

MARGUERITE. A superb strain of these large flowers, which has long been popular.

442 SUPERB MIXTURE. Extra quality. In colors rang. ing from yellow to deep crimson. Pkt. $25 \mathrm{cts}$.

\section{CELOSIA COCKSCOMB}

PLUMOSA. Ostrich Plume Cockscomb. A graceful ornamental feathery strain in many shades of yellow, rose, and crimson.

458 PRIZE STRAIN. Mixed colors. Pkt. 10 cts.

\section{CENTAUREA}

CYANUS. Cornflower; Bachelor's Button. Very showy hardy annuals for planting anywhere, and long have been very popular. It is important to plant only improved, se. lected seed, and to eradicate the volunteers, as they become weedy after several years. 3 feet high.

461 DOUBLE BLUE. A selected strain bearing very large flowers on long stems. Lovely flower for cutting and bed. ding. Pkt. 10 cts.

462 DOUBLE PINK SHADES. A choice selection of variable shades of pink and rose, desirable quality. $\mathrm{Pkt}$. $10 \mathrm{cts}$.
463 DOUBLE WHITE. One of the finest varieties for mixing with other garden flowers. Pkt. $10 \mathrm{cts}$.

464 COLLECTION: One pkt. each of above (3 pkts.), $25 \mathrm{c}$. 465 CHOICE MIXED STRAIN. Pkt. 10 cts., $1 / 4$ oz. 30 cts.

IMPERIALIS. Sweet Sultan. One of the very finest annuals for cutting, with long, graceful stems and beautiful, fluffy towers of delicate fragrance. Strongly recommend. ed. $2 \frac{1}{2}$ feet high

480 MIXED. All colors. Pkt. 10 cts.

468 RICH YELLOW (Suaveolens). This is the yellow Sweet Sultan, a color missing in the Imperialis group, but exactly like it in other respects. Pkt. $10 \mathrm{cts}$.

\section{CLARKIA}

Annuals which enjoy partial shade. They bear double and semi-double flowers on long spikes which are good for cutting. $21 / 2$ feet high.

491 ELEGANS. A mixture of brilliant and very beautiful varied colors. Pkt. 10 cts.

\section{COREOPSIS}

41 GRANDIFLORA. New. A valuable introduction. Flowers rich golden yellow, semi-double, and prettily fluted. A fine border plant and prized for cutting. hP. $3 \mathrm{ft}$. Pkt. $10 \mathrm{cts}$.

\section{COSMOS}

These modern strains of this favorite flower have developed wonderfully large and beautifully tinted flowers, both in the single and the crested types, as well as advancing the date of flowering so that they may be enjoyed for many weeks before being killed hy frost. Use them for back. grounds or corner masses. Their tall growth and feathery foliage are ideal for the purpose.

DOUBLE EARLY ANEMONE-FLOWERED. A new, early-flowering type of greatest merit. The flowers are large, well-colored, and come into bloom in July, lasting until frost.

514 WHITE, PINK and CRIMSON, MIXED. Pkt. 10 cts.

DOUBLE LATE-FLOWERING ANEMONE TYPE. A strain with fine Anemone-type flowers which begin to appear about the middle of August, and continue until destroyed by late frosts.

518 MIXED COLORS. Pkt. 10 cts.

MAMMOTH SINGLE-FLOWERING

NEW GIANT HYBRIDS. Bears lowers 6 to 8 inches in diameter on slender stems, beautifully adapted to cutting.

519 MIXTURE OF DELICATE COLORS. Pkt. $15 \mathrm{cts}$.

EARLY.FLOWERING. A rare large-flowering strain with blooms similar to the above, but beginning to appear extra early and continuing until frost.

523 MIXED. Pkt. 10 cts.

\section{DAHLIAS}

Dahlias may be grown from seed as readily as the commonest garden annuals. If seed is sown in February or March it will produce nice, well-established plants by the time one 


\section{MIGNONETTE}

An old favorite flower which should be freely sown in all flower and shrubbery borders, also on dry banks, walls, and at the margins of paths, and in any sunny, dry situation.

961 ODORATA GRANDIFLORA. Very sweet and old-fashioned. Pkt. 10 cts., $1 / 2$ oz. 25 cts.

965 TRIAL GARDEN MIXTURE. A special selection of seed from large-flowering sorts blended to include yellow, orange, white, crimson, ruby, and bright red. Pkt. 10 cts., $1 / 2$ oz. 40 cts.

\section{MYOSOTIS}

1511 (FORGET-ME-NOT) SCHENLEY'S ALPINE BLUE. The most brilliant blue of all Forget-me-nots. Forms spreading little bushes covered with heads of love. $1 y$, intense deep blue flowers. A grand little bedder and an effective plant for the flower and rock-garden. hP. 8 inches. Pkt. 25 cts.

\section{NASTURTIUMS}

So bright and cheerful and so well known that they need no description, these charming flowers are equally effective as masses in the garden or when cut for indoor decoration.

1001 DWARF, MIXED. A mixture of 22 best named sorts, unexcelled for edging purposes. Sow 1 ounce of seed for 10 to 15 feet of row. Oz. 15 cts. $1 / 4 \mathrm{lb} .50 \mathrm{cts}$., lb. $\$ 1.50$.

1004 IVY.LEAVED, MIXED. Oz. 20 cts., 1/4lb. 70 cts., lb. $\$ 2.00$

\section{PANSIES}

1031 SCHENLEY GARDENS CHOICEST EXHIBITION VARIETIES. Handsome flowers of great size and rich. est colors and markings; strongly recommended for fine individual blooms. Pkt. 35 cts.

1049 MIXTURE OF GIANT TRIMARDEAU VARIETIES. Pkt. 10 cts., $1 / 4 \mathrm{oz}$. 50 cts.

\section{PENTSTEMON}

A most valuable perennial with spikes of very large tubular flowers ranging in color from white to scarlet. They throw up masses of graceful stems bearing spires of beautiful gloxinia-like flowers.

1061 GRANDIFLORUM EXCELSUM. A fine new strain. Pkt. 25 cts.

\section{PETUNIAS}

Perhaps the easiest grown and most satisfactory annuals for continuous show in the garden and for window-boxes. The flowers are greatly variable, and the fine modern varieties display fluted, frilled, fringed, and ruffled forms in selfs, blotches, stripes, and shadings without limit. The seed is very small, and the seedlings, should be given preferred at tention, especially the weaker ones, as they will yield the fnest lowers.
1071 GIANTS OF CALIFORNIA. An American race of great beauty. Fringed and frilled in brilliant colors. Pkt. 25 cts.

KARLSRUHE BALCONY. Imported from Germany, a marvelous, long-branched race, which forms a tapestry of velvet color; especially good for window and porch boxes. The white and pink shades are frequently fringed with. exquisite delicacy. The blue is of the richest, royal shade. Separate colors, per pkt. 25 cts.

1081 WHITE.

1082 DEEP ROSE.

1083 CARMINE.

1084 VIOLET BLUE. 1085 MIXED. 1086 A packet of each for $\$ 1$

\section{PHLOX}

ANNUAL. Sparkling flowers for bright, sunny places, doing well in beds, borders, or on rockwork. They grow easily, reaching a height of 1 to $11 / 2$ feet, and remain in flower until frost.

1099 ALL COLORS, MIXED. Pkt. 10 cts. 1/40z. 50 cts.

PERENNIAL. Tall, hardy plants of utmost value in per. manent borders or shrubbery edgings. Blooms through late summer and fall in great heads of showy flowers.

1100 MIXED. Saved from newest and most beautiful varieties. Blooms second season from seed. Is very slow to germinate. $\mathrm{Pkt}$. $25 \mathrm{cts}$.

\section{HARDY GARDEN PINKS}

575 PERPETUAL-FLOWERING, CLOVE-SCENTED. A new race of hardy garden Pinks producing an abun. dance of very large, richly scented flowers, white, rosepink, crimson, all showing a definite eye of a darker shade. Very bandsome and desirable for borders and cutting. 16 inches. Pkt. 25 cts.

\section{POLYANTHUS}

1526 (PRIMROSE), SPETCHLEY STRAIN, EXTRA SELECTED. Lovely new strain of Giant-flowered Poly. anthus Primroses. The plants are of strong, robust, dwarf growth, and the flowers are of immense size, ranging through a great variety of beautiful colors and art shades. hP. Award of Merit and Silver Flora Medal, R. H. S. Pkt. 50 cts.

\section{POPPIES SHIRLEY POPPIES}

A selected type of graceful habit, producing satiny flowers of great size, on slender stems. Sow seed early, where it is to bloom, as Poppies cannot be successfully trans. planted. 2 feet high.

1131 MIXED COLORS. A gorgeous mixture from select. ed plants in beautiful new shades. Pkt. $10 \mathrm{cts}$.

1137 DOUBLE SHIRLEY POPPIES. An especially fine selection of semi-double and double forms of the famous Shirley Poppies, including white, salmon, pink, crimson, orange, rose, scarlet, cherry-red, all showing yellow an. thers, and sometimes several shades in one flower. $21 / 2$ feet high. Pkt. $15 \mathrm{cts}$. 


\section{OTHER ANNUAL POPPIES}

1145 DOUBLECARNATION-FLOWERED. Very large, handsome, double flowers, fnely fringed, in many brill. iant colors. These Poppies keep much longer than other types after cutting and are extremely showy. Mixed Colors. Pkt. $10 \cdot \mathrm{cts}$., $1 / 4$ oz. 35 cts.

1146 GIANT PEONY.FLOWERED. Bears very large, fine, double flowers of shining colors; very handsome. Mixed. Pkt. 10 cts., $1 / 4$ oz. 35 cts.

1147 FL.ANDERS. Single, dazzling scarlet, very showy flowers, especially valued for its historical associations. Brilliant scarlet. Pkt. $10 \mathrm{cts}$., $1 / 4$ oz. 35 cts.

\section{ORIENTAL POPPIES}

Hardy perennials with finely cut foliage and enormous, showy flowers of striking colors. Blooms second year from seed. 3 feet high.

1151 NEW HYBRIDS, MIXED. Handsome flowers of gorgeous tones of blood-red, fiery scarlet, cherry-rose, salmon-rose, silvery rose-mauve, shrimp-pink, and blush, many blotched with black. Pkt. 25 cts.

ICELAND POPPIES. Hardy biennials with low-growing, tufted foliage. Especially suited for edgings, rockwork, and low borders. 15 inches high.

1161 NEW LARGE-FLOWERED. Remarkably large flowers of pure white, yellow, glowing orange, salmon, pink and apricot. Plit. $25 \mathrm{cts}$.

\section{PORTULACA}

An invaluable hardy annua! for making a carpet of brill. iant color, for edgings, for rockwork, or anywhere a mass of glowing color is wanted. The flowers open only in sunshine. 1171 SINGLE-FLOWERING. A splendid color mixture. Pkt. $10 \mathrm{cts}$.

1172 DOUBLE FLOWERING. Flowers resemble perfect little roses of brightest and richest shades. Pkt. $15 \mathrm{cts}$.

\section{IMPERIAL SALPIGLOSSIS}

An improved strain developed by Vilmorin, a famous seed-grower of France. These gorgeous, velvety flowers delight in a rich, sandy soil, in a sunny place. They may be started early and set out or be sown where they are to flower Do not allow them to crowd, and give lots of water. Splendid for cut-lowers.

1233 ALL COLORS MIXED. Beautiful mixture containing Crimson, Purple, Rose, Scarlet, Violet, Yellow, Blue, and Brown. All finely veined with gold. One of the most superb bedding plants. Pkt. $10 \mathrm{cts}$.

\section{SALVIA}

Useful decorative plants blooming until frost from seed sown early in spring. All are perennial but are best treated as tender annuals. Their flowers are characteristically borne in long, slender spikes which arch gracefully above the bushy foliage.

1212 PATENS. Blue Salvia. Long spikes of gentian-blue flowers. A very popular bedding variety. Pkt. $25 \mathrm{cts}$.
1214 FARINACEA Perennial Salvia. Spikes of soft lav. ender blooms of the utmost decorative value in border and beds. Plant it freely with the lemon-colored African Marigolds. $2 \frac{1}{2}$ to 3 feet high. Pkt. 15 cts.

1557 SALVIA OF THE VATICANGARDENS. Hand. some selected variety of Salvid coming from the Vatican Gardens. It forms a handsome plant 5 feet high, with broad foliage and graceful heads of lavender and white flowers having silvery pink leaf-bracts. A fine woodland plant, seeding freely. bB. Pkt. 25c.

\section{SCABIOSA}

Large-flowered Sweet Scabious; Mourning Bride. Very graceful flowers in quiet, harmonious colors, supremely adapted for cutting because of their long, wiry stems. Also excellent for garden effect in borders, continuing in flower from midsummer until frost. $21 / 2$ to 3 feet high.

1252 ALL COLORS MIXED. Pkt. 10 cts., $1 / 40 z .25$ cts.

\section{STATICE}

A rather large family of "Everlasting Flowers" of very unusual type. They are easily grown and should be plenti. ful in every garden.

1295 MIXED HYBRIDS. Various charming colors. Pkt. 25 cts.

\section{STOCKS}

These are the true Gillyflowers of England, where they are most popular for bedding, pots, and for cut-flowers, both on account of their beauty and their splendid fra. grance. For a succession of bloom, sow at intervals from early March until the last of May. They produce 70 to 75 per cent double flowers; the singles may be detected when quite young and discarded.

GIANT PERFECTION Robust hranching plants $11 / 2$ feet high, with large, handsome flowers over a long period. Blooms from July to autumn if sown early.

1280 ALL COLORS MIXED. Pkt. 15 cts.

\section{SWEET PEAS}

\section{EARLY.FLOWERING SPENCER}

The latest and most valuable improvements in this charming flower which everybody likes and can have. These new varieties are ruffled, frilled, and fluted, like the older Countess Spencer type, but bloom much earlier, consequently they can be planted later in the spring; good for growing in pots or greenhouses.

1329 CHOICE MIXTURE. Pkt. 15 cts., oz. 35 cts.

\section{LATE FLOWERING SPENCER}

Identical to the early type described above, with the same gigantic flowers, but blooming a little later, thus prolonging the season.

1360 UNRIVALED MIXTURE. Pkt. 10 cts., oz. 20 cts., $1 / 4 \mathrm{lb} .60 \mathrm{cts}$. 
is able to plant tubers, and, in consequence, the seedlings are, in most cases, ready to bloom as soon as, if not before, the plants raised from roots. They produce fine Dahlias of rare beauty, equal in many cases to some of the most expensive varieties. It is much more interesting, and certainly much more economical, to raise Dahlias from seed.

532 DOUBLE LARGE-FLOWERING. This seed was secured from twenty named varieties. Pkt. $25 \mathrm{cts}$.

534 DOUBLE POMPON. Includes seed saved from the newest and best varieties. Pkt. 50 cts.

535 SINGLE COLOSSAL. A choice mixture saved from long-stemmed flowers 8 to 9 inches in diameter, with wide perfect petals. Pkt. 25 cts.

537 NEW COLTNESS HYBRIDS, IMPROVED. A charming race of dwarf-growing brilliantly colored Dahlias with single flowers 3 to 4 inches across, ranging from deep crimson to white, and embracing shades of delicate pink, rose, yellow, mauve, scarlet, and purple. Their dwarf, compact habit and persistent blooming make them ideal for bedding purposes, while the long, stiff stems give them unexcelled grace and beauty when used as cut. flowers. The seed germinates quickly and the plants bloom within two months from sowing. Pkt. 25 cts.

\section{MODERN DELPHINIUMS}

48 NEW GIANT HYBRIDS. Seedlings of Countess Cowley, The Shah, W. Pilkington, etc. Flowers of great size, semi-double and double, mostly with light lavender center and blue outer petals, but some of a dark lavender and blue shade. hP. $51 / 2 \mathrm{ft}$. Pkt. $50 \mathrm{cts}$.

541 SCHENLEY GARDENS MAGNIFICENT MIXED. Saved from the finest varieties in pale and silver-blue, mauve, and lavender, with soft and brilliant blues, and the dark and glowing gentian shades. 5 to 7 feet. Pkt. 25 cts.

561 DELPHINIUM BELLADONNA. Azure-blue. Easy to grow. Very beautiful. 3 feet. Pkt. 25 cts.

\section{DIANTHUS}

574 LACINIATUS 6.-pl. Japanese Pink. A new, extralarge, double-flowering type with fringed, lacy petals in a broad range of colors. White, Orange, Scarlet, Salmon, Crimson, and Rosy Purple. Pkt. 15 cts.

\section{DIDISCUS}

590 CÆRULEA. Blue Lace Flower. Dainty light blue flowers in lace-like heads. Very fine for cutting. 2 feet high. Pkt. 15 cts.

\section{DIGITALIS - FOXGLOVE}

THERE are soft harmonies of color-tones and a quiet dignity of form when the slim spires of Foxgloves gather before a shrubbery or a wall; and when they rise outlined against the sky they have the lissome symmetry of wild, uncaptured things.

Plant sweet williams and pinks about their feet, or creamy violas. Let hardy asters grow among them, to bloom when they are gone.
591 THE SHIRLEY. A new, large-flowered variety 5 to 7 feet tall, with shafts of rose and pink and pure white flowers spotted with crimson, and maroon, and chocolate. Pkt. 10 cts.

592 ISABELLINA. Golden yellow flowers which pale to cream and chamois. You ought to see them in a bed of pale blue forget-me-nots! Pkt. $40 \mathrm{cts}$.

\section{ESCHSCHOLTZIA - CALIFORNIA POPPY}

Remarkably attractive plants for bedding or edging. They are exceptionally good for planting with nigella. Sow from April to June where they are to lower as they do not transplant well. We have made a special effort to obtain many beautiful shades.

629 BRILLIANT MIXTURE. Pkt. 15 cts.

\section{GAILLARDIA}

One of the most useful hardy perennials, growing vigorously under all conditions of culture and neglect. Equally good for garden decoration and cutting.

641 PERENNIAL VARIETIES MIXED. Seed saved from a collection of the very best new sorts. Pkt. 25 cts.

642 DAZZLER. Brilliant flowers, 5 inches across, of pure golden yellow with a rich red center, so harmoniously proportioned that while it loses nothing of the bril. liancy, it has much more grace and refinement than the common varieties. Stems long and erect; unexcelled for cutting. Pkt. 25 cts.

643 GAILLARDIA, NEW PORTOLA HYBRIDS.

Fine new strain of vigorous growth, producing very large, handsome, broad-petaled flowers ranging through shades of bronzy red with golden-tipped petals. $\mathrm{hP} .21 / 2 \mathrm{ft}$. Pkt. $25 \mathrm{cts}$.

\section{GODETIA}

Very beautiful annuals for spring and summer borders, making sturdy little bushes covered with large fowers of brilliant, delicate shades. They seem to enjoy hot, dry summers.

695 MIXED. Saved from many rare and variegated shades of the best named varieties. Pkt. 10 cts.

\section{GYPSOPHILA}

Baby's Breath. The annual and perennial varieties are in great demand for combining with other cut-flowers. In order to have the annual in flower all summer, replant oc. casionally throughout the season.

711 ELEGANS GRANDIFLORA ALBA. Annual. An improved strain, giving clouds of delicate white flowers on graceful sprays. Pkt. 10 cts.

712 ELEGANS GRANDIFLORA ROSEA. Annual. Similar to the above, except that the flowers are rosy scarlet with white centers. Pkt. $10 \mathrm{cts}$.

713 PANICULATA. Perennial. Produces clouds of tiny, mistlike flowers unsurpassed for garden decoration and cutting. 2 feet high. Pkt. $10 \mathrm{cts}$.

714 PANICULATA FLORE-PLENO. Perennial. A double-flowering form of the preceding. Ptt. $25 \mathrm{cts}$. 


\section{HELICHRYSUM}

By far the most important of the Everlasting or Straw. flowers. They grow rapidly to 3 to 4 feet and make showy border plants throughout the summer. Cut the flowers before the centers unfold, strip off the foliage, and hang up. side down in a cool, dry place, so the stems will dry straight. There are unusually fine colors mixed here, such as white, salmon, and violet which are seldom seen in the usual winter bouquets.

741 ALL COLORS MIXED. Pkt. 10 cts.

\section{HOLLYHOCKS}

Stately ornamental plants 6 to 10 feet high which are in dispensable for making striking color effects in the garden. We offer Chater's Prize Strain of double flowering sorts, which is generally considered the finest type.

765 SCARLET. Pkt. 10 cts. 766 YELLOW. Pkt. 10 cts. 769 CHATER'S PRIZE STRAIN. Beautiful mixture of colors. Specially selected. Pkt. 10 cts.

772 DOUBLE AND SEMI-DOUBLE EARLY FLOWERING. Blooms in July from spring'sown seeds. White, primrose, flesh-pink, deep rose, scarlet, cherry, and purple. 6 to 10 feet high. Pkt. 10 cts.

773 DOUBLE IMPERATOR. An enormously improved Hollyhock, bearing flowers $51 / 2$ to $61 / 2$ inches across, with wide, elegant, deeply frilled outer petals, centered by a close rosette about 2 inches across. The whole sug. gests a Crested Begonia on a giant scale. It comes in multitudinous colors and shades, such as cerise, salmon with cream and rose center, delicate pink with rose and yellow center, light yellow flushed rose, with canary'yellow center, and many others. The sturdy plants branch vigorcusly from the base, making majestic clumps with strong stems which can be cut for decorative purposes. Pkt. 30 cts.

\section{IPOMOEA}

These are the bold-leaved Morning-Glories and Moonflowers.

803 RUBRA CÆRULEA (Heavenly Blue.) A rare, ethereal color of elusive charm. Pkt. 10 cts.

805 CARDINAL CLIMBER. A rapid-growing vine with clouds of scarlet stars. Pkt. 25 cts.

806 IMPERIAL JAPANESE MORNING-GLORIES. Ruffled, fluted towers in unbelievable shapes and colors. Pkt. 10 cts., oz. 35 cts.

\section{LARKSPUR - ANNUAL DELPHINIUM}

Larkspurs are splendid cutting flowers which come into bloom early and last long. The long spikes of bloom should be cut freely, to give the plant opportunity to form new blooms on the side-shoots at the base. It should be sown as soon as the ground can be worked, in the place where it is to bloom, as the seedlings do not flourish as a rule, after being transplanted. Rigorous thinning of the seedlings must not be overlooked as the plants should stand nearly a foot apart each way.

DWARF DOUBLE EMPEROR STRAIN. The finest type of bedding Larkspur yet produced. Strong, erect plants and handsome spikes of semi-double flowers 1 to $11 / 2$ feet high.

561 SPECIAL MIXTURE OF APPLE-BLOSSOM, ROSEWHITE, AND LIGHT BLUE SHADES. Pkt. 15 cts., $1 / 40 z .50 \mathrm{cts}$.

TALL DOUBLE STOCK.FLOWERED. Very handsome, large, semi-double flowers especially fne for garden dis. play. $21 / 2$ feet high.

562 AGERATUM-BLUE.

563 DEEP VIOLET.BLUE.

564 BRIGHT ROSE-PINK.

565 PURPLE.

566 DEEP ROSE.

567 SC.ARLET-ROSE.

568 WHITE.

569 WHITE, STRIPED LIGHT.BLUE.

570 MIXED. All the above colors.

Any of above, pkt. $10 \mathrm{cts.,} 1 / 40 z .25 \mathrm{cts}$.

\section{LATHYRUS}

Perennial Sweet Pea. Strong climber suitable for covering old stum ps, walls, and fences. Produces a profusion of sweetpea-like flowers on fine stems for cutting. Not fragrant.

841 MIXED COLORS. Pkt. 15 cts.

\section{LUPINES}

THESE exquisite flowers are badly misunderstood. In spite of a wolfish name, they are neither savage nor rapacious, but so thoroughly domesticated that they delight in dry, sterile soil, and upon hot, sunny banks. They actually thrive upon neglect.

892 BLUE CLOUD. Long sprays of soft rosy tinted blue. 4 feet. Pkt. 30 cts.

899 LADY CONST ANCE. Soft blue and silvery white. 3 feet. Pkt. 30 cts.

909 SUNSHINE. The prize-winning golden flowered, longsprayed variety. 4 feet. Pkt. 30 cts.

915 NEW HYBRIDS, MIXED. Saved from many beautiful colors. Pkt. 35 cts.

\section{MARIGOLDS}

AFRICAN. Tall, strong-growing annuals with ferny foliage, producing strongly scented, double, ruffled flowers in great profusion. One of the best annuals.

941 PRIZE STRAIN, ORANGE. Pkt. 10 cts.

942 PRIZE STRAIN, LEMON. Pkt. $10 \mathrm{cts}$.

943 MIXED, ORANGE AND YELLOW. Pkt. 10 cts.

FRENCH MARIGOLDS are the midgets of the family, with small rosettes of gold and crimson.

956 SILVER KING. Lemon-yellow and maroon. This is the one we like the best. Pkt. 10 cts.

\section{MECONOPSIS}

959 BAILEYI. The most beautiful of all the Tibetan Pop. pies, discovered by Captain Kingdom Ward in Tibet as a woodland plant. It has a leafy stem, surmounted by several large, saucer-shaped flowers of a delightful sky. blue color, with golden stamens. hP. $4 \mathrm{ft}$. Pkt. $50 \mathrm{cts}$. 
SWEET WILLIAM

(Dianthus barbatus). Richly colored heads of flowers in great sheets of bloom. One of the finest plants for edging wide beds or for planting in masses. They are perennials, but are best treated as annuals or biennials. 12 to 15 inches high.

1376 DOUBLE VARIETIES MIXED. A special selection of colors; very large flowers. Pkt. 10 cts.

\section{VERBENA}

Most desirable, brilliantly flowering bedding plants, keeping low and spreading widely, forming broad mats of gorgeous color. Easy to grow and continues in flower a long time.

1390 NEW LARGE-FLOWERED HYBRIDS. New types distinguished for wide range of color and size of bloom. They come in scarlet, rose, pink, blue, purple, whiteall showing a sparkling eye which enhances their beauty. Compact growth. Pkt. 25 cts.

\section{WALLFLOWERS}

Fragrant hardy perennials which require a light shelter in regions of very severe winters. They produce handsome spikes of very showy llowers in early spring. Our collection is very large, and we offer many heretofore unobtain. able varieties.

1431 EXTRA-EARLY PARISIAN. Blooms the frst year from seed. Early sowings in March will flower in summer, and May and June sowings will bloom in autumn and, in mild climates, throughout the winter. Delight. fully fragrant. Mixed colors including orange, gold, red, and primrose. Pkt. 25 cts.

\section{ZINNIAS}

The common Zinnias of yesteryear have gone for good, and, without losing their robust strength or their eagerness to grow and bloom, the modern Zinnias have acquired a greater size, an elegance of form, and a refinement of texture in fitting with their new and sparkling colors.

NEW CALIFORNIA DAHLIA.FLOWERED ZINNIAS Per Packet 15 cts.

1588 BURNT.ORANGE. Flowers double, very large, some nearly 5 inches across, brilliant golden orange to golden yellow. Sturdy, branching habit. hhA. 20 in. Pkt. 25 cts.

1455 CRIMSON MONARCH. Gigantic flowers some. times 8 inches across. Rich red.

1461 DREAM. A pure shade of mallow-purple and lavender.

1451 EXQUISITE. Truly Dahlia-flowered. Light rosepink, with a darker center.

1452 OLD ROSE. A shadowy rose tint of utmost charm. We like it tremendously.

1467 SPECIAL GOLD MEDAL MIXTURE. A mix. ture of the named varieties described above, Pkt. $15 \mathrm{cts}$.

PICOTEE. An odd type having each petal outlined by a contrasting color. The range of hues is similar to the Double Giants, and about 70 per cent show the charac. teristic picotee edge. A most interesting novelty, useful to provide variety in the section of the garden devoted to Zinnias, but they are especially adapted for use as cut-flowers.

1472 ALL COLORS MIXED. Includes the very new white and scarlet shades. Pkt 15 cts.

\section{MODERN GLADIOLUS}

\section{At Wholesale Prices}

ALICE TIPLADY (Prim.). bright saffron-orange; large open flowers on strong, stiff stem; excellent cutflower and furcer. Price per 10 bulbs, $36 \mathrm{cts}$.

CRIMSON GLOW, glowing, velvety crimson, shaded deeper in the center; tall, strong grower, flowers well placed; considered the best in its color. Price per 10 bulbs. $48 \mathrm{cts}$.

EVELYN KIRTLAND, very warm rose pink, deeper at the edges of the petals shading towards shell pink in the center, brilliant scarlet blotches on the lower petals; strong stem, making it one of the most desirable varieties for cutting. Price per 10 bulbs. 54 cts.

GOLDEN MEASURE. pure golden yellow; very large flowers of good substance; robust grower and considered the best yellow on the market; a superglad. Price per 10 bulbs, 66 cts.

MINUET, beautiful clear, light lavender, four to six large, heavily tex. tured blooms open at once on a good, strong stem. This is the lavender by which all other lavenders are judged. Considered by most growers as the last word in a light lavender gladiolus. Price per 10 bulbs, $\$ 1.44$.

MR. W. H. PHIPPS, La Prance pink, overlaid with salmon rose, lighter towards the center, lower petals fantly striped and speckled with ruby; enormous flowers, as many as 20 open at a time and perfectly placed on gigantic stem; a real super glad. Price per 10 bulbs, 84 cts.

MRS. FRANK PENDLETON, deep rose pink shading to pale pink in throat, large, bright crimson blotches on lower petals, giving it a striking appearance; tall, vigorous grower; extra cutflower and forcer. Price per 10 bulbs, 45 cts.

PFITZER'S TRIUMPH, a super-gladiolus, one of the best ever intro. duced; color resembles the variety $\mathrm{Dr}$. Bennett, but the flowers are still larger and of twice the substance; also better shape and nicer form, meas. uring 6 to 7 inches in diameter, color bright orange-salmon with small velvet red mark in throat. It is absolutely irresistible. Imagine a five. foot tall spike, the last flower of which, either in water or out in the field, opens up in perfect shape, retains its full color, and is still as big as an America. Price per 10 bulbs. $\$ 1.95$.

ROSE ASH, old rose overlaid and blended with pink, blue and red, giving the color of ashes of roses, hence its name; large flowers on tall strong spikes; very attractive. Price per 10 bulbs, 54 cts.

WILBRINK, lesh pink with yellowish blotch on lower petals; large, well placed lowers on tall, strong stems; the frst pink to bloom, together with Halley, of which it is a sport, extra good cutflower and forcer. Price per 10 bulbs, 45 cts. 